\title{
Synthesis, Characterization and Thermal Study of New Transition Metall Complexes Derived from 3-Acetylcoumarine.
}

\author{
TaghreedM. Musa ${ }^{1}$, Mahmoud N. Al-jibouri² ${ }^{2}$ BayaderF. Abbas ${ }^{3}$. \\ Chemistry department, college of science, AL-Mustansiriyauniversity, Baghdad, Iraq \\ taghreedmohya@yahoo.com ${ }^{1}$, mahmoudnajim71@yahoo.com2, bayaderfadhil@gmail.com $^{3}$
}

\begin{abstract}
The synthesis, structure, physico-chemical and thermal investigation studies of some transition metal complexes of $\mathrm{Co}(\mathrm{II}), \mathrm{Ni}(\mathrm{II}) \mathrm{Cu}(\mathrm{II})$ and $\mathrm{Cd}(\mathrm{II})$, withtwo ligands derived from 3-acetyl coumarine. The two ligands ligands $\left(\mathrm{L}^{1}\right.$ and $\left.\mathrm{L}^{2}\right)$ were synthesizedvianucleophilic substitution of 3-bromoacetylcoumar with potassium thiocyanateandethanolic solution of 1,2-phenlendiaminein respectively. The metal complexes of $\mathrm{Co}(\mathrm{II}), \mathrm{Ni}(\mathrm{II}) \mathrm{Cu}(\mathrm{II})$ and $\mathrm{Cd}(\mathrm{II})$, with $\mathrm{L}^{1}$ and $\mathrm{L}^{2}$ were prepared and isolated in the solid state then characterized by CHNM elemental spectral FT-IR, ${ }^{1} \mathrm{H},{ }^{13} \mathrm{CNMR}$, Mass spectra,UV-Visible spectra. The thermal study (TG-DSC) of some complexes was carried out in nitrogen gas which assisted in determination the proper structure and formula of such complexes. The ligand acts as bidentate, through 00 or NO, neutral in coordinating the metal ions under study. The results obtained from elemental analyses,magnetic susceptibility and electronic spectra suggested that all metal complexes were formed in 2:1 molar ratio of ligand to metal with octahedral structures. The complexes are found to be soluble in DM F and DM SO. The TG-DSC study revealed that the metal complexes were thermally stable with point decomposition over $350^{\circ} \mathrm{C}$ as well as the percent in loss of weight up on decomposition at inert conditions of nitrogen atmosphere has reported the proposed formula.
\end{abstract}

Key Words: nucleophilic substitution of 3-bromoacetylcoumarin, Transition metal complexes of Chromone-2-one and Ligationalbehaviour of Cumarine ligands.

\section{Introduction}

Transition metal complexes of cumarineligandshave been studied and attract attention against the antitumor activity [1-3].In particular metal chelates of cumarine have been known for some time to be antitumor agents $[4,5]$. Because of their biological activity and analytical application,thiosemicarbazidesandthiosemicarbazones, as well as theirmetal complexes have been the subject of many studies $[6,7]$. The Schiff bases of coumarins comprise a very large class of Lewis bases that have interested in the field of coordination chemistry [8]. The antimicrobial activity of coumarin nucleus and related derivatives [9] has a great important effects like antibacterial, antithromboticandvasodilators[10].As it hasinvestigated in the literature the biological activity of some coumarinderivatives significantly enhances by binding to metal ions[11,12]. In continuation with this interest of cumarine chelates, we report the synthesis, characterization and thermal study of some first row transition metal complexes with two ligands derived from 3-bromoacetyl-cumarine-2-one.

\section{Experimental}

All chemicals were of reagent grade, and solvents were dried and distilled before useaccording to the standard procedures. 3-Acetylcoumar-2one in was purchased from Sigma-Aldrich company and other starting materials like potassium thiocyanate and 1,2-phenylenediamine were supported from laboratories of chemistry department,college of science-Al-M ustansiriyauniversity. The hydrated chlorides $\mathrm{CoCl}_{2} \cdot 6 \mathrm{H}_{2} \mathrm{O}, \mathrm{NiCl}_{2} \cdot 6 \mathrm{H}_{2} \mathrm{O}, \mathrm{CuCl}_{2} \cdot 2 \mathrm{H}_{2} \mathrm{O}, \mathrm{CdCl}_{2} \cdot 2 \mathrm{H}_{2} \mathrm{O}$ and $\mathrm{Cd}\left(\mathrm{CH}_{3} \mathrm{COO}\right)_{2}$ were purchased from Alfa company, and were used without further purification as received. The measurements of molar conductivity were made on an Hanna conductivity bridge with cell constant $1.0 \mathrm{~cm}^{-1}$. The magnetic susceptibilitymeasurements were made on a 
Gouy balance at room temperature using $\mathrm{Hg}[\mathrm{Co}(\mathrm{SCN}) 4]$ as calibrant on Sherewood magnetic balance. The vibration spectra were recorded in a $\mathrm{KBr}$ and CsI matrix using a Shimadzu FTIR spectrometer model 983 .The electronic spectra in the range (200-1000 nm) were done for all complexes and the free ligands complexes in DMF and ethanol solutions were scanned on aCarry 2390 instrument.1H and 13C-NMR spectra were determined on Burker DMX- 500 NMRSpectrophotometer on a $300 \mathrm{MHz}$, with TMS as standard and DMSO as solvent (Alalbayt University-Jordan).TG and DSC( Differential Scanning Colurimetry) thermo grams in different ranges were carried out at (R.T) heating rate $=10 \mathrm{C}^{0} / \mathrm{min}$ (Linseis STA PT-1000) were run in Baghdad university Abinhitham collage. The metal contents of the complexes were determined by Atomic Absorption measurements were performed by using the instrument Analytic Jena / A Spect LS /FL 1.3.0.0, Ibn-CinaCenter, Ministry of Industry. Magnetic moment for prepared complexes in the solid state at room temperature were measured according to Faraday's method using: Auto Magnetic susceptibility Balance Sherwood Scientific. AL- Mustansiriyah University. The chloride content for complexes were determined by Mohr's method. Mass spectra were performed using the instrument: GC MS -QP 2010 VLTRA, AL- Mustansiriyah University.

\subsection{Synthesisof $\omega$-bromo-3-acetylcoumarine}

The bromination of (1) in acetic acid gave $\omega$-bromo-8- 3-acetylcoumarin (2), [12] (Scheme 1) .

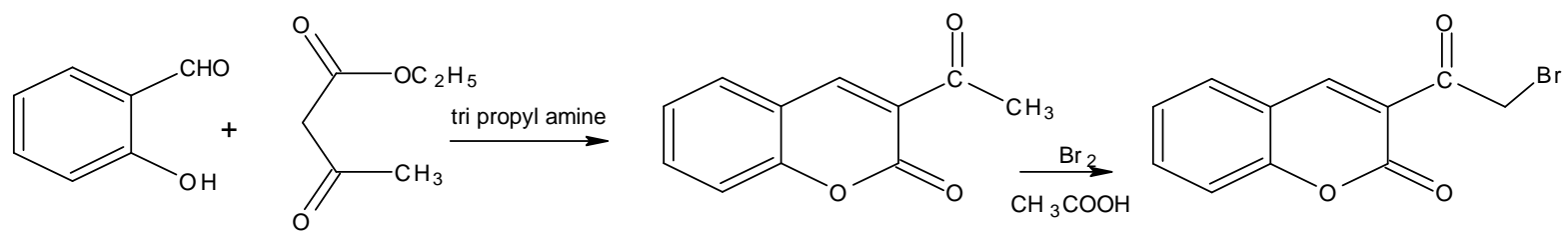

Scheme 1.Synthesisof $\omega$-bromo-3-acetylcoumarine.

2.3. Synthesis of 3-(quinoxalin-2-yl)-cumarine (3). $\left[L^{1}\right]$

A solution of (2) (5 mmol) and 1,2-phenylenediamine ( $5 \mathrm{mmol})$ in absolute methanol $(20 \mathrm{~mL})$ was refluxed for 4hours. The solid obtained was filtered, washed with ethanol and dried under vacuum. The crude product was recrystallized from ethanol/benzene mixture to give compound 11 as pale brown crystals; yield 77\%; m.p. 148 $150^{\circ} \mathrm{C}$, Scheme 2.

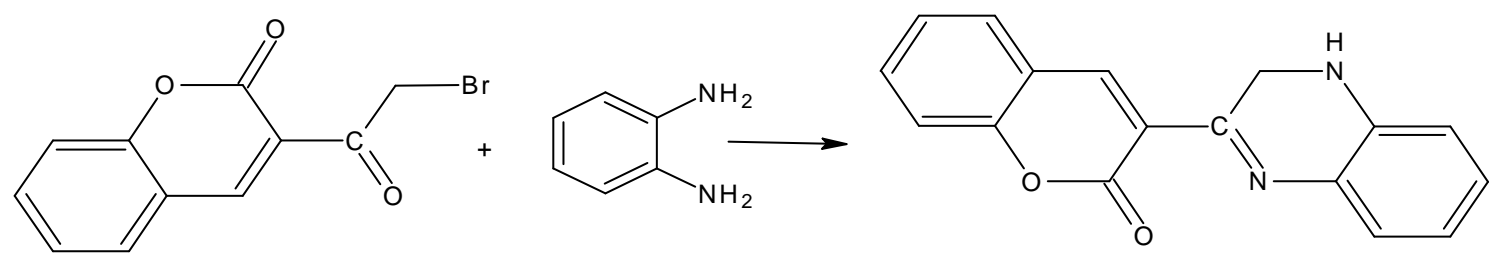

Scheme2 . Synthesis of . $\left[L^{1}\right.$

2.4. Synthesis of 2-methylene-2H-chromene-3-(methyl carbonimidic)thioanhydride (5). $\left[\mathrm{L}^{2}\right]$

A solution of compound (2) $(10 \mathrm{mmol})$ in methanol $(40 \mathrm{~mL})$ was refluxed with potassium thiocyanate $(10 \mathrm{mmol})$ for 3 hours. The solid formed on cooling filtered off, washed with ethanol and dried under vacuum. The product was then recrystallized from acetic acid to give 16 as brown needles; yield 90\%; m.p.138 -- $140{ }^{\circ} \mathrm{C}$,Scheme 3 . 

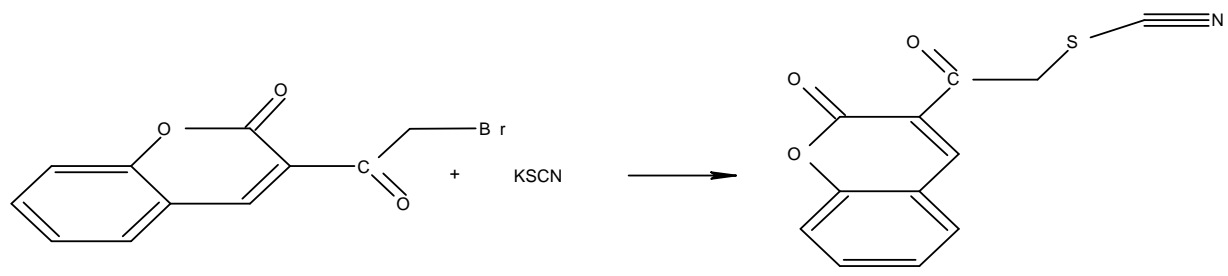

Scheme 3.Synthesis of $\left[L^{2}\right]$.

\subsection{Synthesis of the Metal complexes}

A mixture of $\mathrm{L}^{1}$ and $\mathrm{L}^{2}$ ( $2 \mathrm{mmol}$ )in $50 \mathrm{~mL}$.ethanol was added to an aqueous solution of Cadmium (II) Chloride dihydrate, nickel(II) chloride hexahydrate, Cobalt(II) Chloride hexahydrate and copper(II) chloride dihydrate (1 $\mathrm{mmol}, 10 \mathrm{ml}$ ). The mixture of reaction was refluxed for approximately2-3 hours and then excess solvent was distilled. The coloured complexes so obtained were filtered, washed with methanol and dried under vacuum over calcium chloride pellets., Yield: $70-85 \%$.

$$
\begin{aligned}
& 2 \mathrm{~L}_{1}+\mathrm{CdX}_{2} \cdot 2 \mathrm{H}_{2} \mathrm{O} \longrightarrow\left[\mathrm{Cd}\left(\mathrm{L}^{1}\right)_{2}\right] \cdot \mathrm{X}_{2} \\
& \mathrm{X}=\mathrm{CH}_{3} \mathrm{COO} \text { or } \mathrm{Cl}
\end{aligned}
$$

Scheme 4.Synthesis of the $\mathrm{Cd}(\mathrm{II})$ complexes

Results \& Discussion

\section{Analyses and physical measurements}

All the complexes are sparingly soluble in common organic solvents but highly soluble in DMF and DMSO. The analytical data (Table 1) indicate that the complexes are mononuclear with 2:1 molar ratio of ligand to metal ion. The molar conductance in DMF fall in the expected range for their non-electrolytic behaviour, indicating that the chloride ions are inside the coordination while the Cd(II) complexfall in the expected range for their electrolytic behaviour, indicating that the chloride ions are outside the coordination sphere and

\section{Mass spectra}

The figure(1) clearly exhibits the molecular ion peak $\mathrm{m} / \mathrm{e}=188$ which agree well with the formula $\mathrm{C}_{11} \mathrm{H}_{8} \mathrm{O}_{3}[13]$. As well as the bromination of 3-acetyl cumarine (A) by $\mathrm{Br}_{2}$ in chloroform solution leads to A2 derivative which it's mass spectra in figure(2) displays base peak at 267 that is consistent with $\mathrm{C}_{10} \mathrm{H}_{7} \mathrm{O}_{3} \mathrm{Br}$. However the other peaks at 186 and 88 are extremely attributed $\mathrm{M}-\mathrm{Br}+\mathrm{ion}$. The ring closure of 1,2-phenylenediamine with A2derivative,scheme(3) results in ligand $L 1$ which shows molecular ion $\mathrm{m} / \mathrm{e}=274$ at relative intensity $100 \%$ then supports the proposed structure of $\mathrm{L}^{1}$ ligand.On the other hand the figure(3) represents the mass spectra of $\mathrm{L} 2$ ligand which shows absorptions at245, 244,192,160,128 and 81 that are assigned to $\mathrm{C}_{12} \mathrm{H}_{7} \mathrm{NSO}_{3}$ and fragments of $\mathrm{M}-\mathrm{SCN}, \mathrm{M}-\mathrm{CH}_{2} \mathrm{SCN}$ and base peak of $\mathrm{C}_{5} \mathrm{H}_{5} \mathrm{O}+$ respectively[14,15],figure(3). 


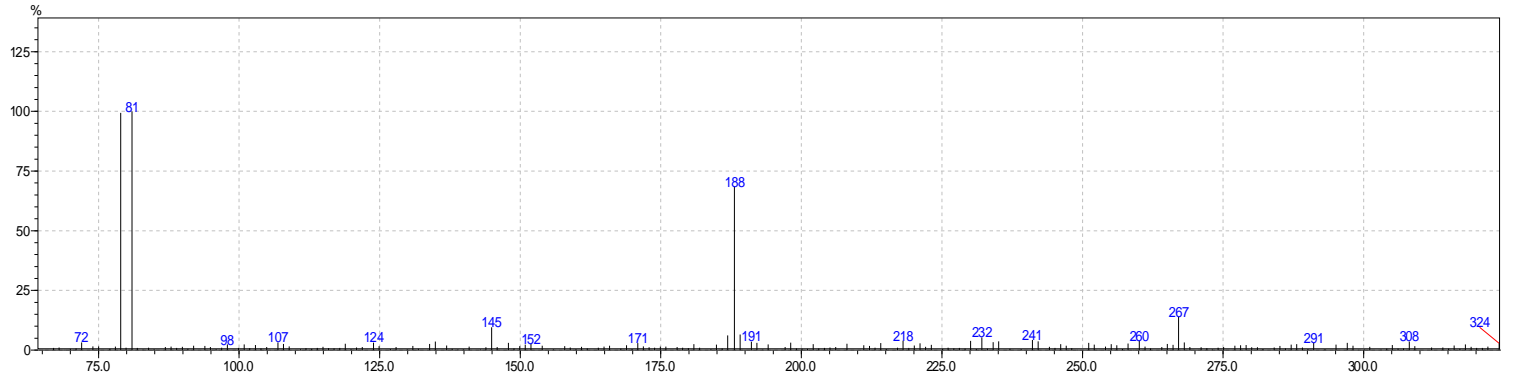

Figure 1.Mass of $\omega$-bromo-3-acetylcoumarine

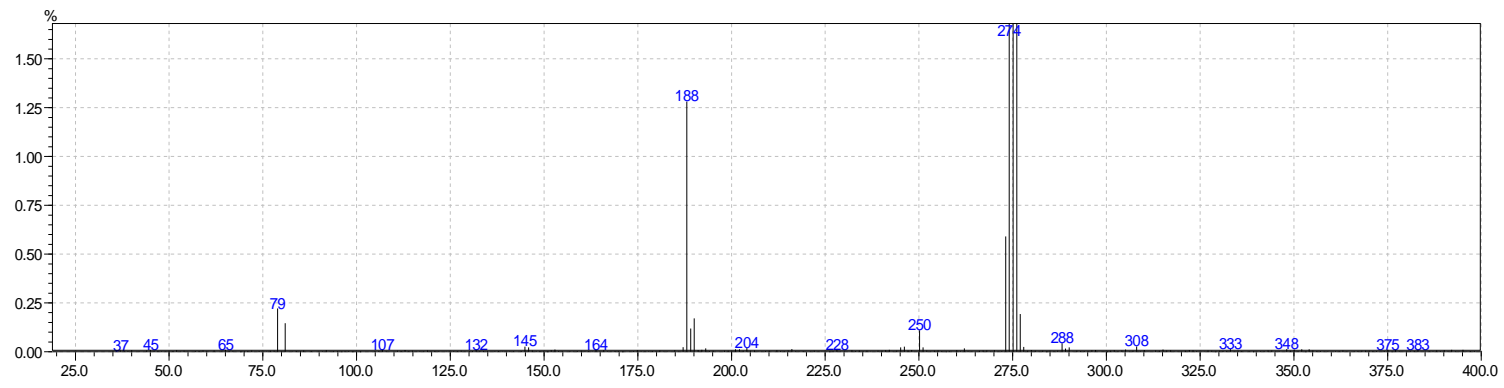

Figure 2 .Mass of $\mathrm{L}^{1}$.

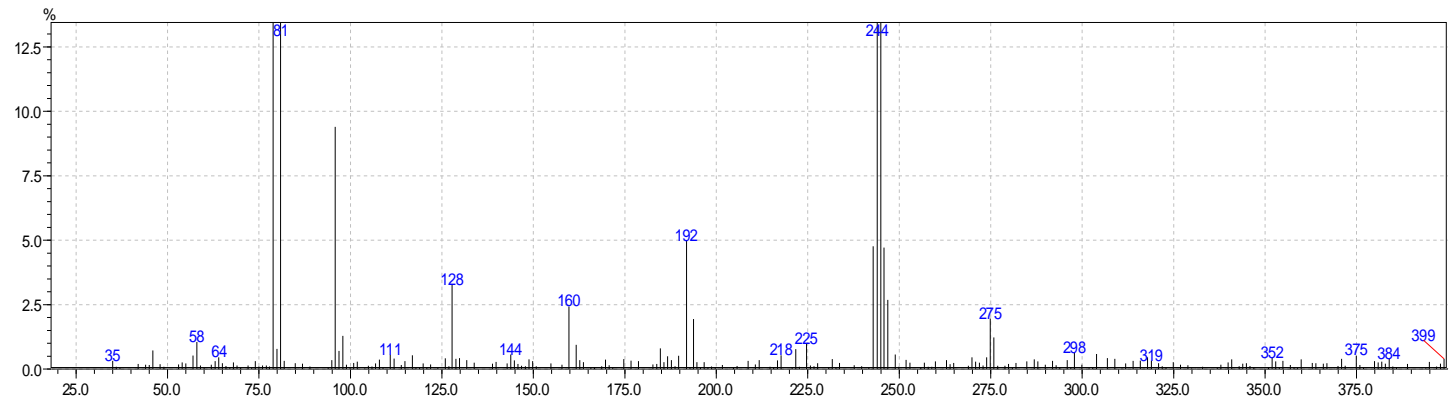

Figure 3 .Mass of $\mathrm{L}^{2}$.

\section{Infrared spectra}

The bromination of 3-acetylcumarine have proved by the medium bands at 780 and $870 \mathrm{~cm}^{-1}$ that are attributed to $\mathrm{H}_{2} \mathrm{C}-\mathrm{Br}$ moiety[12].The distinct bands at 2962, 1710, and $1630 \mathrm{~cm}^{1-}$ in the IR spectra of $\mathrm{L} 2$ may be assigned to aliphatic $-\mathrm{CH}_{2}-$,carbonyl of chromone and $-\mathrm{C}=\mathrm{C}$ - moiety respectively [12]. As well as the spectra of ligand $\mathrm{L}^{1}$ formed from cyclo addition of $A$ with 1,2-phenylenediamine was approved from appearance singlet absorption at 3370 $\mathrm{cm}-1$ and strong absorptions at 1712 and $1630 \mathrm{~cm}-1$ which are assigned to $-\mathrm{C}=0$ and $-\mathrm{C}=\mathrm{N}$ - of quinoxaline moiety[13].M ain characteristic infrared absorption bands of the 3-acetylcumarine $A$ and their derived ligands L1 and $\mathrm{L} 2$ with their $\mathrm{Ni}(\mathrm{II}), \mathrm{Co}(\mathrm{II}), \mathrm{Cu}(\mathrm{II})$ and $\mathrm{Cd}(\mathrm{II})$ complexes, along with their assignments, are presented in Table 2. The free 3-acetylcoumarin) shows band at $1730 \mathrm{~cm}-1$ is attributed to $(C=0)$ of the lactone ring [13]. The stretching vibration is observed at $2130 \mathrm{~cm}-1$ with a shoulder on lower wave number side may be assigned to -S-CN moiety. The observed medium intensity band at $912 \mathrm{~cm}-1$ in the free $\mathrm{L}^{2}$ ligand, which is ascribed to $\delta(\mathrm{CSC})$ of $-\mathrm{SCN}$ - moiety vibration [15], did not subject to remarkable changes in the spectra of solid complexes suggesting no involvement of the sulfur atom in the bonding with the metal's ions [15]. The medium intensity band observed at $1570 \mathrm{~cm}-1$ is assigned to $(C=C)$ of the chromoneringthe comparison of the positions of these bands with those observed in the infrared spectra of its $\mathrm{Ni}(\mathrm{II}), \mathrm{Co}(\mathrm{II}), \mathrm{Cu}(\mathrm{II})$ and $\mathrm{Cd}(\mathrm{II})$ complexes indicated that the band at $1670-1705 \mathrm{~cm}-1$ showed 
a marked shift, this discussed that carbonyl group shared in the complexation toward $\mathrm{Ni}(\mathrm{II}), \mathrm{Co}(\mathrm{II}), \mathrm{Cu}(\mathrm{II})$ and $\mathrm{Cd}(\mathrm{II})$ ions, while that bands at 3328 and $3306 \mathrm{~cm}-1$ which assigned to stretching vibration motions $-\mathrm{O}-\mathrm{H}$ moiety is good proof for presence of coordinated water molecules[14]. This fact suggests the coordination of L2 through the nitrogen $-\mathrm{S}-\mathrm{CN}$ and oxygen of lactone $-\mathrm{C}=0$ together and tending to form stable complexes. The observed medium intensity band at $912 \mathrm{~cm}-1$ in the free $\mathrm{HL}$ ligand, which is ascribed to $\delta(\mathrm{CSC})$ of thiocyanato group attached directly to - $\mathrm{CH} 2$ - moiety [15], shifted to lower values for the five $\mathrm{HL}$ complexes, suggesting the involvement of the sulfur atom in the bonding with the metal's ions. The band assigned to the stretching of $v(C-S)$ is similarly shifted to lower frequencies. This also confirms that the sulfur atom is taking part in the complex formation [16]. On the other hand, the weak to medium intensity absorptions in the regions 400-470 and 490-544 cm1- are ascribed to $\mathrm{M}-\mathrm{O}$ and $\mathrm{M}-\mathrm{N}$ bonds [17].

\section{Magnetic measurements}

The magnetic susceptibilities of the complexes, recorded at room temperature (Table-3) show low magnetic moments indicating the presence of a spin exchange interactions between the metal ions. The values obtained of copper(II) complexes lie in the 1.73-1.85 BM range and corresponds to one unpaired electron. As well as the orbital contributions of cobalt (II) and nickel(II) complexes in the ranges 4.2-4.6 and 3.50-3.22 BM respectively indicated the high spin octahedral structures around Co(II) and Ni(II) ions[18,19].

\section{Electronic spectral studies}

Electronic spectral data of the complexes in DMSO solution are listed in Table(3). The ligands $\mathrm{L}^{1}$ and $\mathrm{L}^{2}$ exhibited similar spectral features in the UV-Vis region with bands around 255, 310 and 440 nmrespectively. The first band below $310 \mathrm{~nm}$ is assigned to a ligand transition $\left(\mathrm{n}-\pi^{*}\right)$ and $\left(\pi-\pi^{*}\right)[10,14]$. The other two bands, 370 and $440 \mathrm{~nm}$ are attributed to charge transfer processes. The visible spectra of all the complexes are similar and show an intense absorption band near $\sim 360 \mathrm{~nm}$ and moderately intense shoulder band near 395-415 nm and distinct band at $\sim 656$ $\mathrm{nm}$. The separated weak energy bands of copper (II) complex in the range 550-871 nm could be attributed to ${ }^{2} \mathrm{~B}_{1} \mathrm{~g} \rightarrow$ ${ }^{2} \mathrm{~B}_{2} \mathrm{~g}$ and ${ }^{2} \mathrm{~B}_{1} \mathrm{~g} \rightarrow{ }^{2} \mathrm{Eg}$ transitions respectively and support the formation of distorted octahedral around $\mathrm{Cu}(\mathrm{II})$ ion [17]. The weak absorptions at 810,650 and $440 \mathrm{~nm}$ of cobalt(II) complex formed with $\mathrm{L}^{1}$ ligand may be assigned to ${ }^{4} \mathrm{~T}_{1} \mathrm{~g} \rightarrow{ }^{4} \mathrm{~T}_{2} \mathrm{~g},{ }^{1} \mathrm{~T}_{1} \mathrm{~g} \rightarrow{ }^{4} \mathrm{~A}_{2} \mathrm{~g}$ and ${ }^{4} \mathrm{~T}_{1} \mathrm{~g} \rightarrow{ }^{4} \mathrm{~T}_{1} \mathrm{~g}(\mathrm{P})$ respectively [18]. The spectrum of the green complex of $\mathrm{Co}$ (II) formed with L2 ligand exhibited the following absorptions at $860 \mathrm{~nm}, 690 \mathrm{~nm}$ and $567 \mathrm{~nm}$ these peaks are characteristic of octahedral cobalt (II) complex respectively [12, 17].By the same way, the nickel(II) complex formed with L1 and L2 ligands showed two spin-allowed transitions at 410, $395 \mathrm{~nm}$ and 840and550 $\mathrm{nm}$ that are remarkably belonged to ${ }^{3} \mathrm{~A}_{2} \mathrm{~g} \rightarrow{ }^{3} \mathrm{~T}_{2} \mathrm{~g}$ and ${ }^{3} \mathrm{~A}_{2} \mathrm{~g} \rightarrow{ }^{3} \mathrm{~T}_{1} \mathrm{~g}$ suggesting the octahedral geometry around $\mathrm{Ni}(\mathrm{II})$ ion respectively [18]. However, the cadmium(II) complexes formed with L1 showed only absorptions in the 393,361nm and 401,365 $\mathrm{nm}$ indicating the charge transfer and the benzenoid bands of coumarine ring[10,11].The absorptions in the regions 378,340 and $393,363 \mathrm{~nm}$ attributed to the cadmium chloride and cadmium acetate(II) complexes formed with L2

\section{NMR Spectra}

The ${ }^{1} \mathrm{H}$-NM R spectra of the L1 ligand in d6-DM SO solventTable.3 shows multiple signals at 6.5-7.90 ppm, corresponding to the eight protons aromatic ring protons of the phenyl and pyrazine moieties [15]. The singlet at $4.60 \mathrm{ppm}$ was attributed to the two protons of the - $\mathrm{CH} 2-\mathrm{Br}$ group [10]. The signal of the $-\mathrm{NH}$ proton in the quinoxaline moiety was observed at $9.55 \mathrm{ppm}$, and the singlet peak at $8.77 \mathrm{ppm}$ is attrinuted to $\mathrm{H}-\mathrm{C}=\mathrm{C}-$ in position 4 of coumarinering,figure (4). As well as the figure(5) shows the $C^{13} \mathrm{NM} \mathrm{R}$ of L1 in d6-DM SO which displays resonance peaks related to aromatic $-\mathrm{C}=\mathrm{C}$ - in the regions $113-125 \mathrm{ppm}$ and $127-131 \mathrm{ppm}$ are assigned to $-\mathrm{C}=0$, - 
$\mathrm{C}=\mathrm{N}$ - and - $\mathrm{C}-\mathrm{N}$ moieties respectively. The figures $(5,6)$ show the ${ }^{1} \mathrm{H}$ and ${ }^{13} \mathrm{C} \mathrm{nmr}$ spectra of $\mathrm{L} 2$ in d6-DM SO where the absorptions in the region 6.2-7.80 ppm are ascribed to $\mathrm{Ar}-\mathrm{H}$ protons and the chemical shift at 8.04-8.70 ppm is assigned to protons of annulated coumarine ring[12,13]. The singlet peak at $11.40-11.50 \mathrm{ppm}$ may be attributed to $\mathrm{H}-\mathrm{C}=\mathrm{C}$ of coumarine ring in $\mathrm{C} 4$ position. However, the weak peak at $4.10 \mathrm{ppm}$ could be assigned to $\mathrm{CH} 2-\mathrm{Br}$ due to effect of electron withdrawing effect of bromine and thiocyanato groups on the deshielding of aliphatic protons toward the weak magnetic field [20].

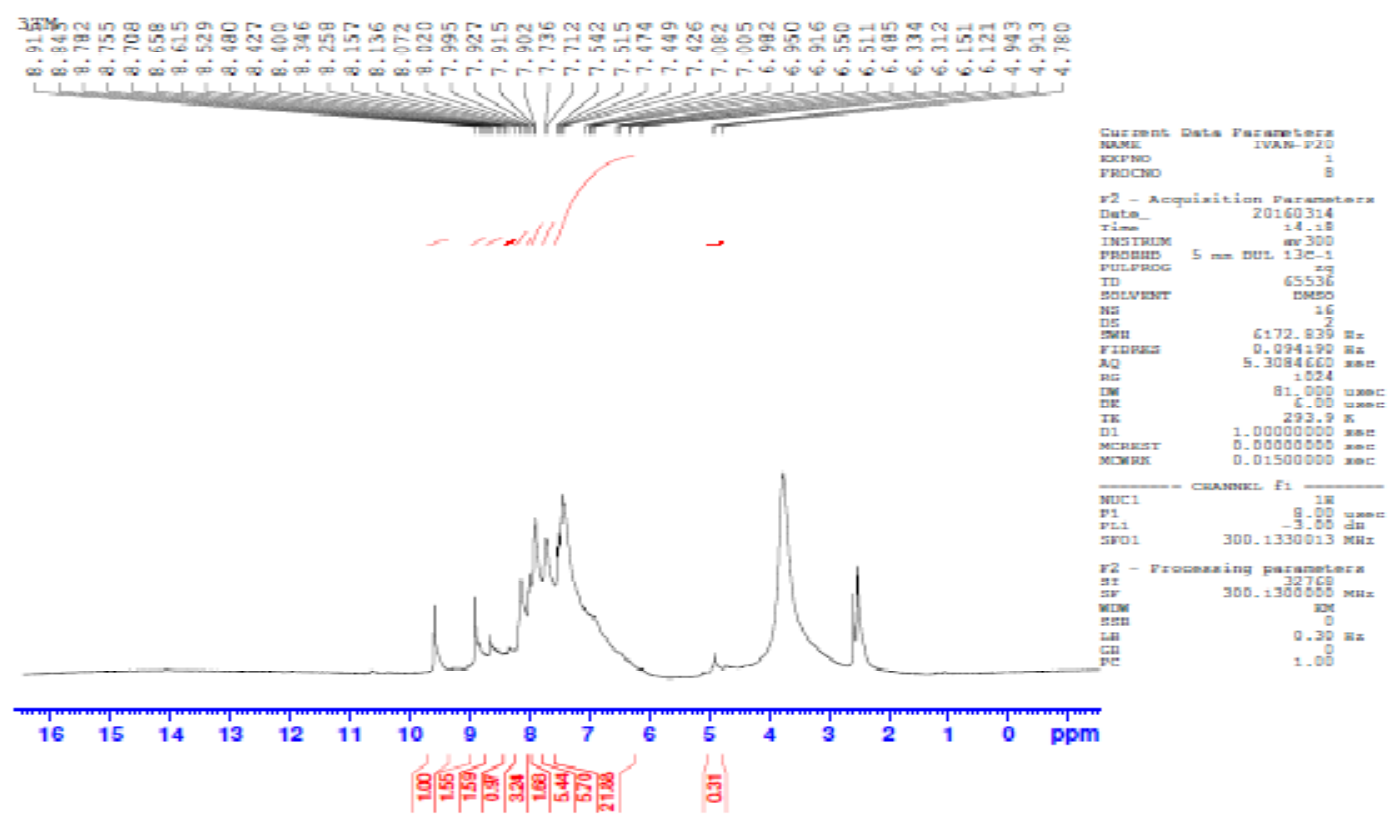

Figure 4. H NM R spectra of $L^{1}$ in DM SO- $d 6$ solvent

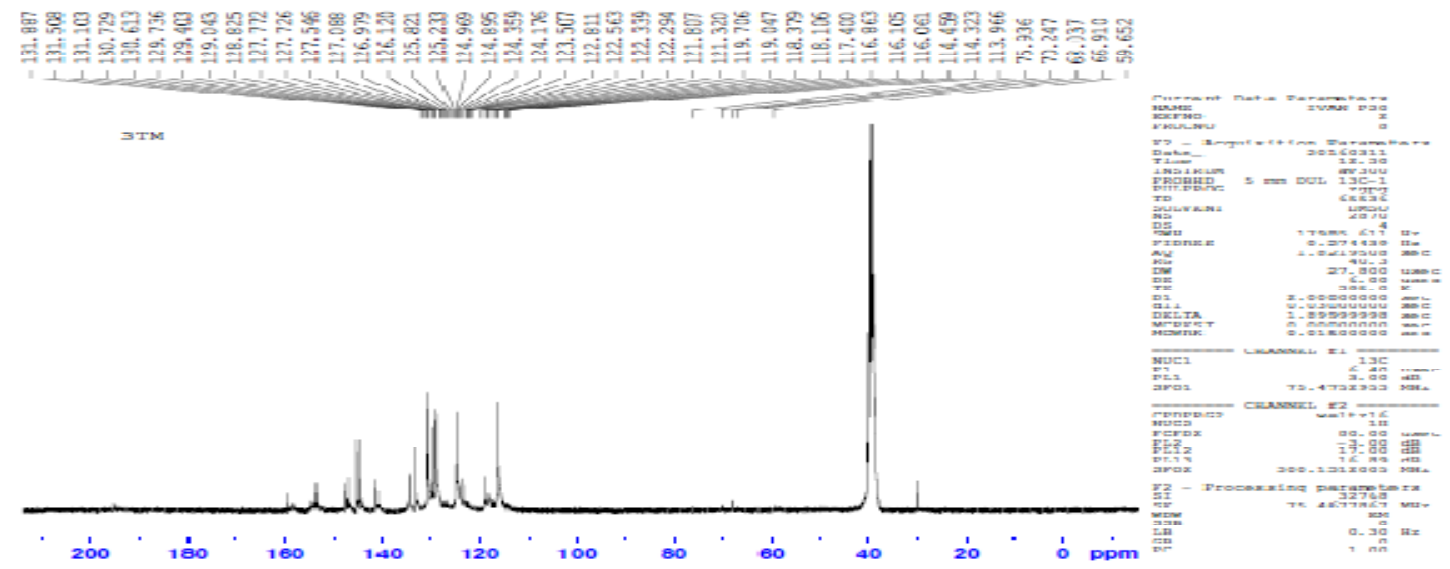

Figure $5 .{ }^{13}$ C NM R spectra of $L^{1}$ in DM SO- $d 6$ solvent. 


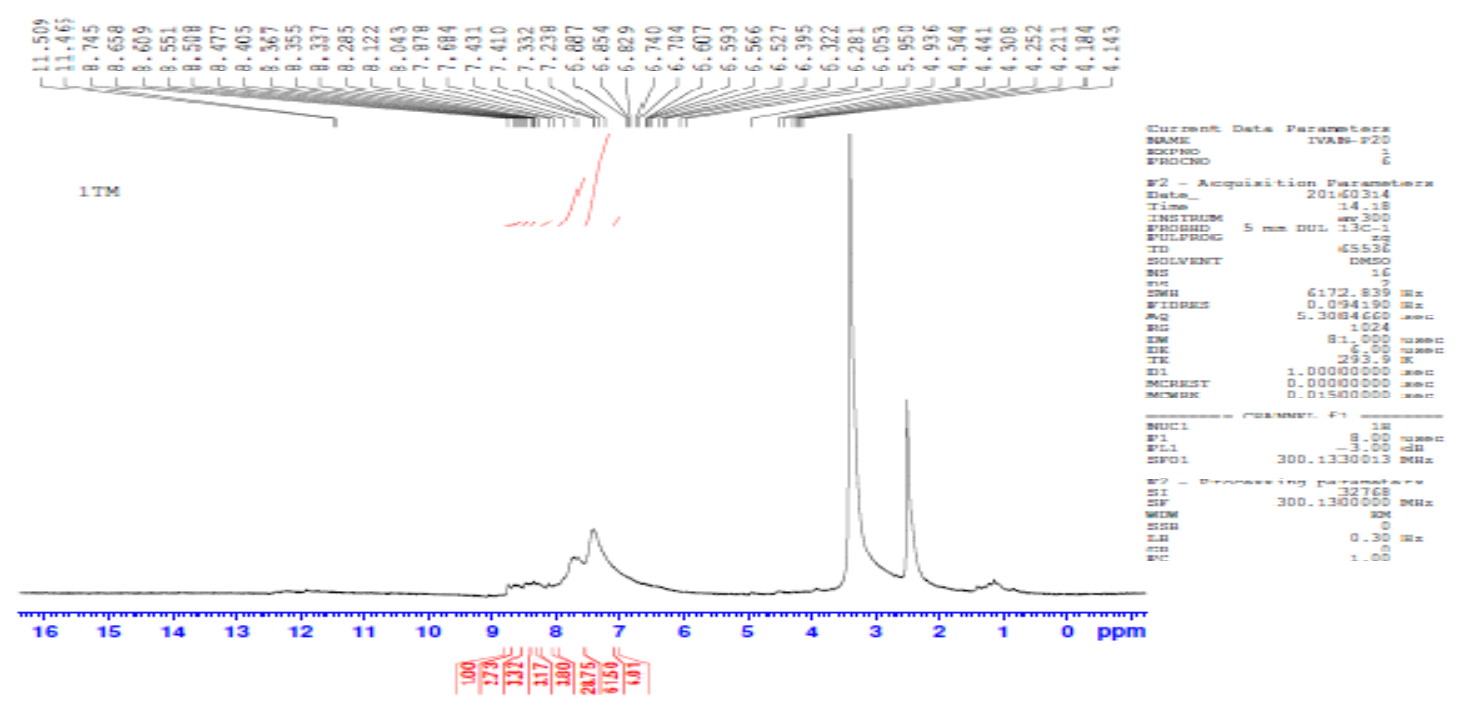

Figure 6.H NMR spectra of $L^{2}$ in DM SO d6 solvent.

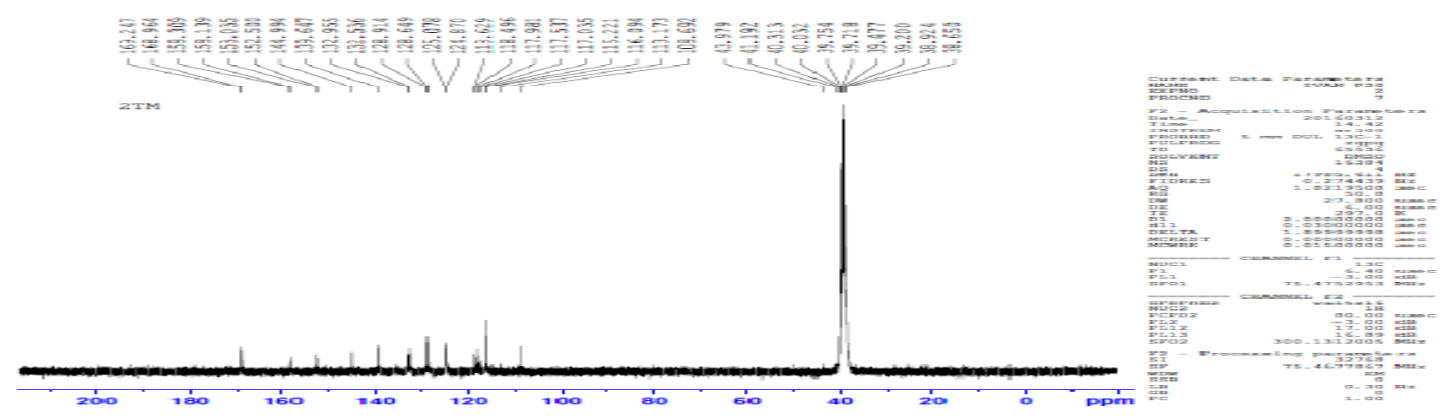

Figure $7 .{ }^{13}$ C NMR spectra of $L^{2}$ in DM SO- $d 6$ solvent.

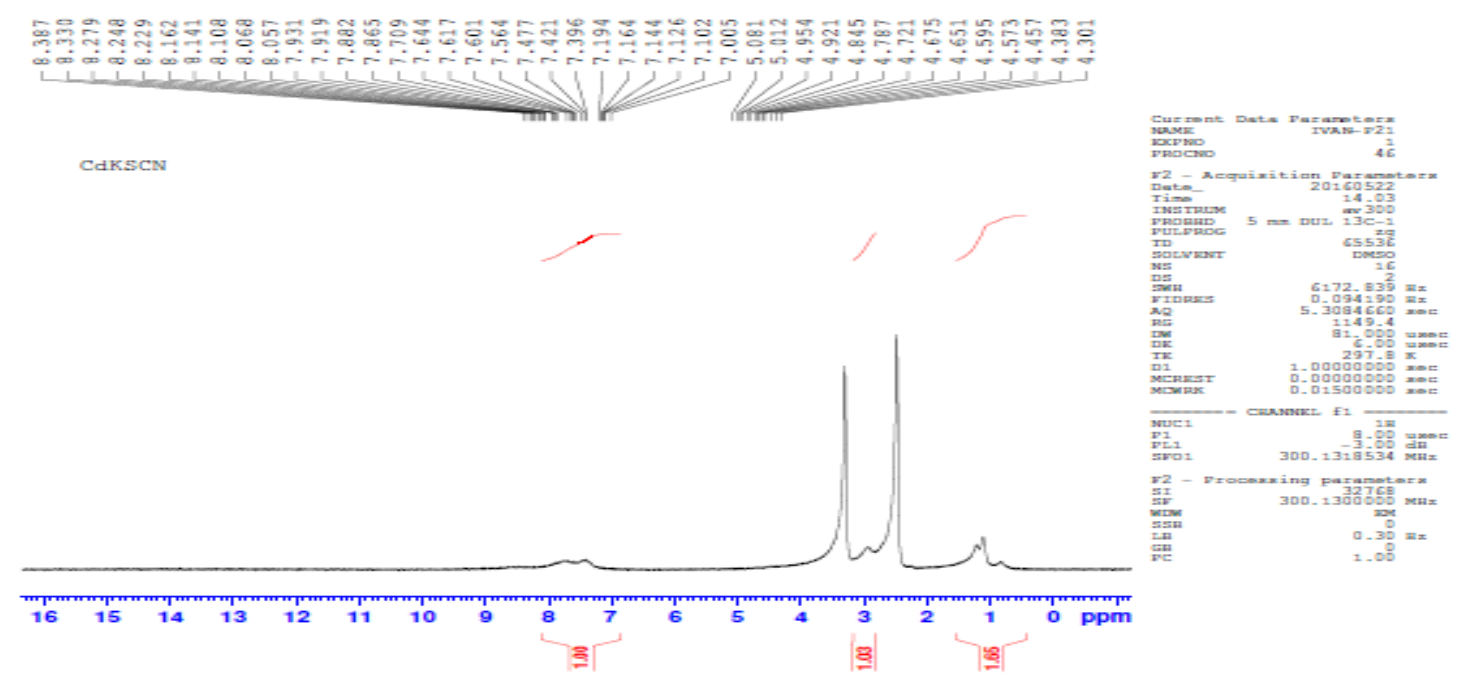


Figure 8. ${ }^{1} \mathrm{HNM} R$ spectra of $\left.\left[\mathrm{Cd} \mathrm{L}_{2}\right](\mathrm{OAC})_{2}\right]$ in DM SO $d^{6}$ solvent.

\section{Thermal analysis}

The thermal degradation of $\mathrm{Co}(\mathrm{II}), \mathrm{Cu}(\mathrm{II})$ and $\mathrm{Cd}$ (II)fig.9,10 complexes was studied using thermo gravimetric techniques and a temperature range of $25-360^{\circ} \mathrm{C}$. The thermal stability data are listed in Table 6 . The data from the thermo gravimetric analysis clearly indicated that the decomposition of the complexes proceeds in three or four steps. Ethanol molecules were lost between $50-63.63^{\circ} \mathrm{C}$.All complexes were lost hydration water molecules between $100-119{ }^{\circ} \mathrm{C}$. The removal of water can proceed in one or two steps. Complex $\mathrm{Cu}(\mathrm{II})$ lost hydration water and ethanol molecules between 50 and $120^{\circ} \mathrm{C}$. The DSC analysis fig. 11 of $\mathrm{Cu}(\mathrm{II})$ complex with $\mathrm{L}^{1}$ ligand associated endothermic peaks have been detected over temperatures $\left(122^{\circ} \mathrm{C}\right)$ as indicated by DSC analysis . the corresponding values of entropy of activation $\Delta \mathrm{s}^{*}$, were in range -0.547 to $-0.480 \mathrm{jmole}^{-1}$. the negative values of $\Delta H^{*}$ means that the decomposition processes are endothermic The degradation pathway for all complexes may be represented as follows:

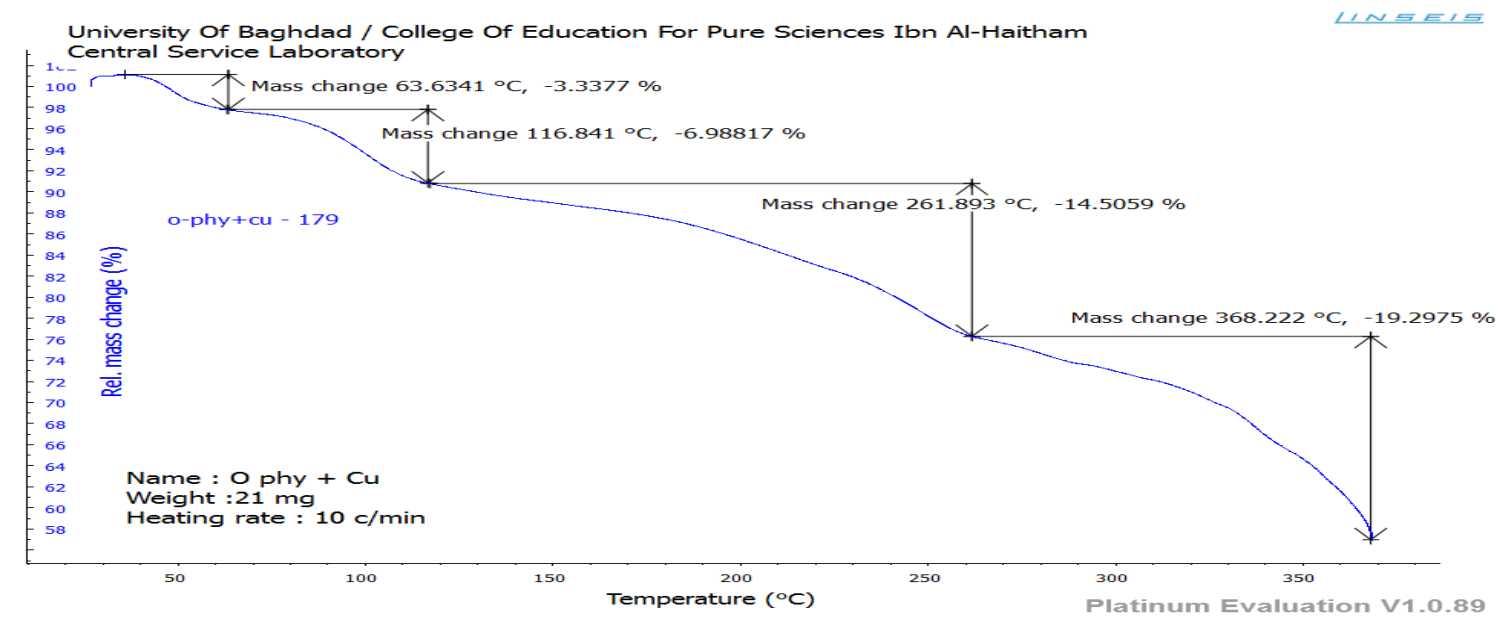

Figure 9.TGFigure 5.TG analysis of $\mathrm{Cu}(\mathrm{II})$ complex with $\mathrm{L}^{1}$ ligand. 


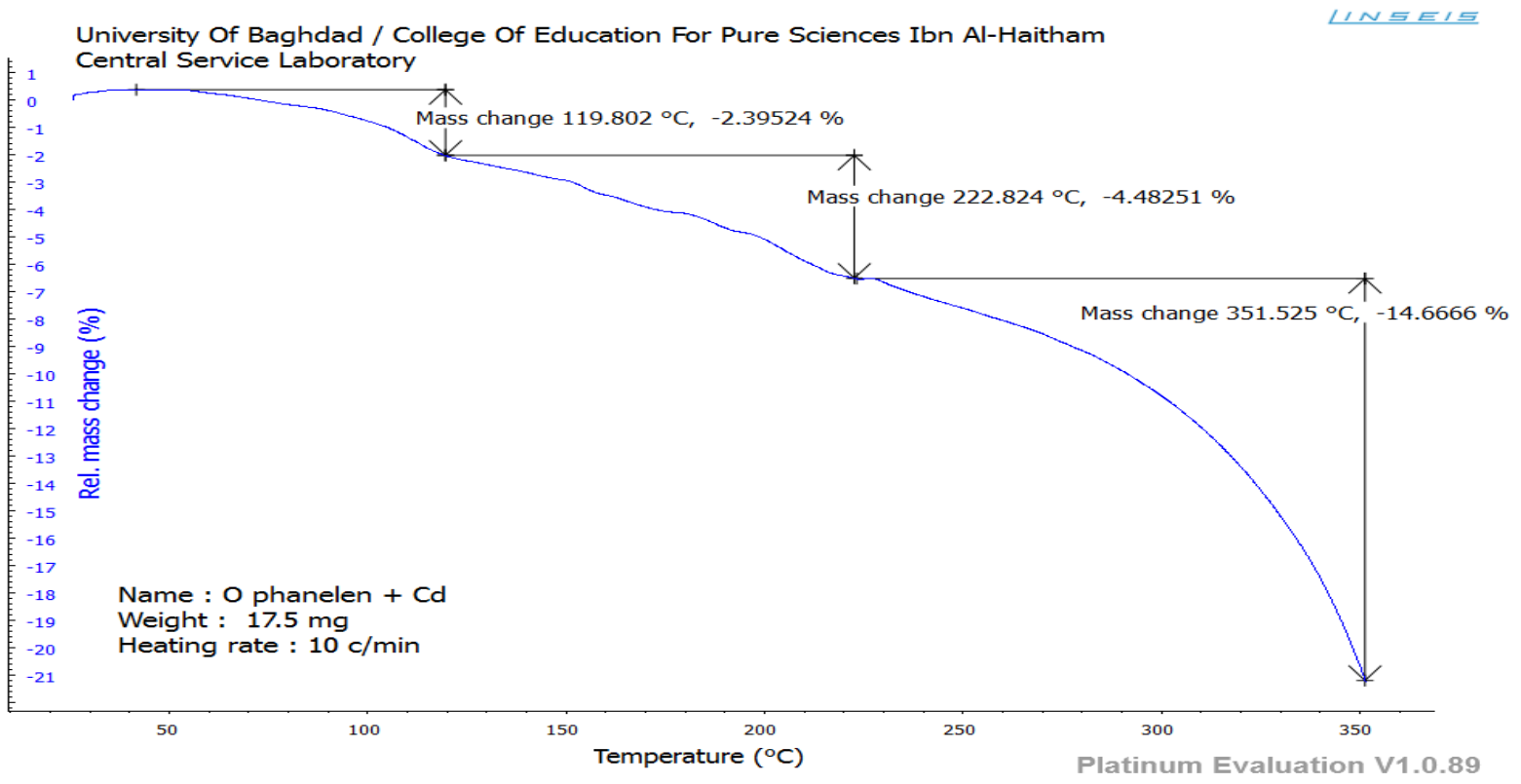

Figure 10.TGanalysis of $\mathrm{Cd}(\mathrm{II})$ complex with $\mathrm{L}^{1}$ ligand.

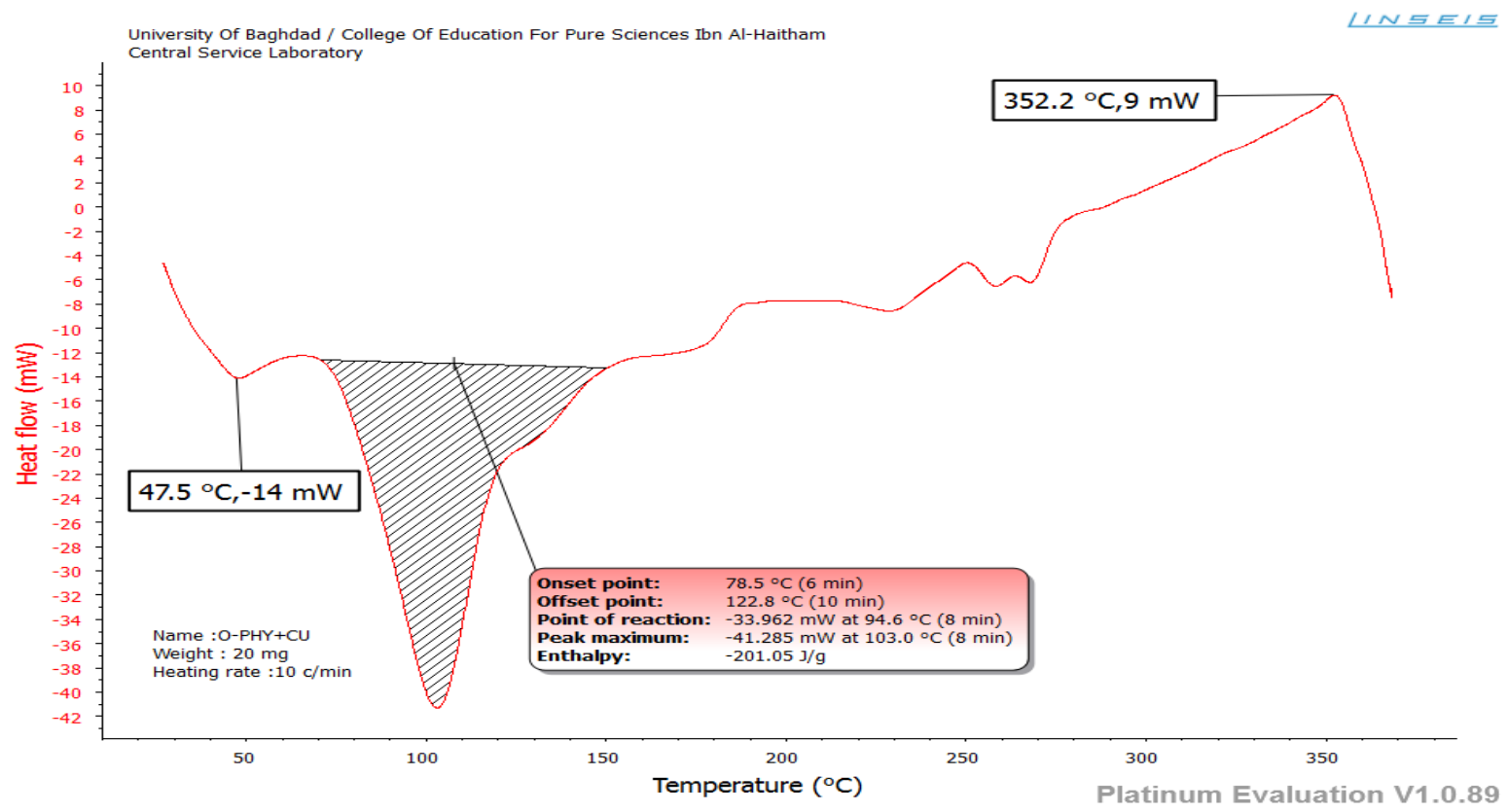

Figure 11.DSC analysis of $\mathrm{Cu}(\mathrm{II})$ complex with $\mathrm{L}^{1}$ ligand. 


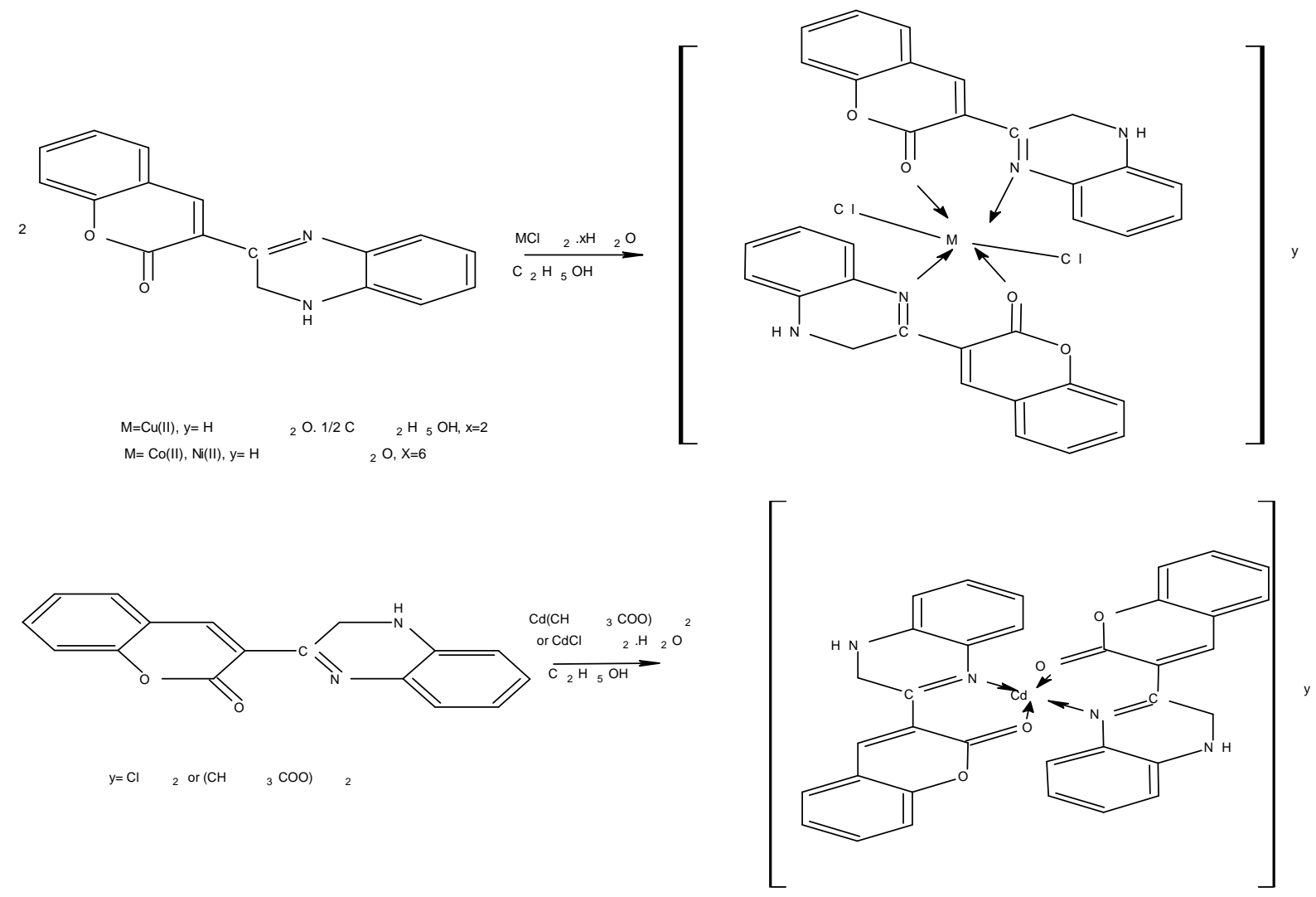

Scheme 5.synthesis of complexes of $L^{1}$.

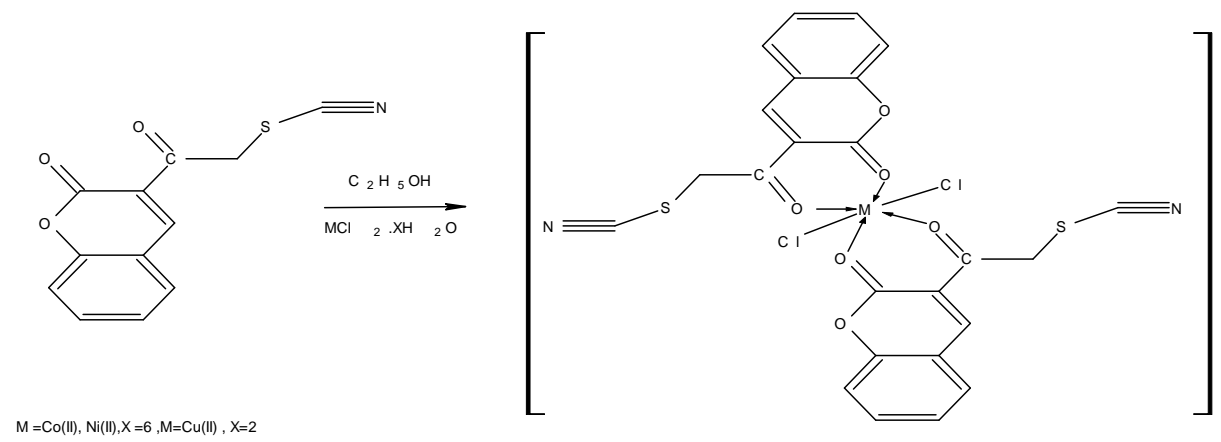

Scheme 6 ,synthesis of complexes of $L^{2}$. 
Table 1.The physical properties and elemental analysis of the prepared metal complexes.

\begin{tabular}{|c|c|c|c|c|c|c|c|c|c|}
\hline Formula & Color & $\begin{array}{l}\mathrm{Mwt} \\
\mathrm{g} / \mathrm{mol}\end{array}$ & $\begin{array}{l}\text { M.p. } \\
\left({ }^{\circ} \mathrm{C}\right){ }^{a}\end{array}$ & $\begin{array}{l}\mathrm{C} \% \\
\text { Calc } \\
\text { (Found) }\end{array}$ & $\begin{array}{l}\mathrm{H} \% \\
\text { Calc } \\
\text { (Found) }\end{array}$ & $\begin{array}{l}\mathrm{N} \% \\
\text { Calc } \\
\text { (Found) }\end{array}$ & $\begin{array}{l}\mathrm{S} \% \\
\text { Calc } \\
\text { (Found) }\end{array}$ & $\begin{array}{l}\mathrm{M} \%{ }^{\mathrm{b}} \\
\text { Calc } \\
\text { (Found) }\end{array}$ & $\begin{array}{l}\mathrm{Cl} \% \\
\text { Calc } \\
\text { (Found) }\end{array}$ \\
\hline $\mathrm{C}_{17} \mathrm{H}_{12} \mathrm{O}_{2} \mathrm{~N}_{2}\left[\mathrm{~L}^{\mathrm{I}}\right]$ & Brown & 276 & $\begin{array}{l}148- \\
150\end{array}$ & $\begin{array}{l}73.90 \\
(73.02)\end{array}$ & $\begin{array}{l}4.38 \\
(4.23)\end{array}$ & $\begin{array}{l}10.14 \\
(10.19)\end{array}$ & - & - & \\
\hline$\left[\mathrm{C}_{34} \mathrm{H}_{22} \mathrm{O}_{4} \mathrm{~N}_{4} \mathrm{Cl}_{2} \mathrm{Co}\right] . \mathrm{H}_{2} \mathrm{O}$ & Brown & 698.41 & $\begin{array}{l}182 \\
(\mathrm{Dec})\end{array}$ & $\begin{array}{l}58.47 \\
(58.02)\end{array}$ & $\begin{array}{l}3.46 \\
(3.16)\end{array}$ & $\begin{array}{l}8.02 \\
(8.27)\end{array}$ & - & $\begin{array}{l}8.44 \\
(8.17)\end{array}$ & 10.15 \\
\hline$\left[\mathrm{C}_{34} \mathrm{H}_{22} \mathrm{O}_{4} \mathrm{~N}_{4} \mathrm{Cl}_{2} \mathrm{Ni}\right] \cdot \mathrm{H}_{2} \mathrm{O}$ & Brown & 698.14 & $\begin{array}{l}161- \\
163\end{array}$ & $\begin{array}{l}58.49 \\
(58.17)\end{array}$ & $\begin{array}{l}3.46 \\
(3.12)\end{array}$ & $\begin{array}{l}8.79 \\
(8.92)\end{array}$ & - & $\begin{array}{l}8.02 \\
(7.89)\end{array}$ & $\begin{array}{l}10.16 \\
9.96\end{array}$ \\
\hline$\left[\mathrm{C}_{34} \mathrm{H}_{24} \mathrm{O}_{4} \mathrm{~N}_{4} \mathrm{Cl}_{2} \mathrm{Cu}\right] \cdot \mathrm{H}_{2} \mathrm{O}$ & Purple & 643.14 & $\begin{array}{l}198 \\
(\mathrm{Dec})\end{array}$ & $\begin{array}{l}64.40 \\
64.11\end{array}$ & $\begin{array}{l}4.13 \\
3.98\end{array}$ & $\begin{array}{c}8.84 \\
8.90\end{array}$ & - & $\begin{array}{l}10.02 \\
9.95\end{array}$ & \\
\hline $\begin{array}{c}{\left[\mathrm{C}_{34} \mathrm{H}_{26} \mathrm{O}_{5} \mathrm{~N}_{4} \mathrm{Cd}\right] \mathrm{OAC}} \\
{\left[\mathrm{C}_{36} \mathrm{H}_{29} \mathrm{O}_{7} \mathrm{~N}_{4} \mathrm{Cd}\right]}\end{array}$ & Beige & 742.04 & $\begin{array}{l}189- \\
191\end{array}$ & 58.27 & 3.94 & 7.55 & - & $\begin{array}{l}15.15 \\
14.89\end{array}$ & - \\
\hline$\left[\mathrm{C}_{34} \mathrm{H}_{26} \mathrm{O}_{5} \mathrm{~N}_{4} \mathrm{Cd}\right] \mathrm{Cl}_{2}$ & $\begin{array}{l}\text { Beigi } \\
\text { Beige }\end{array}$ & 717.45 & $\begin{array}{l}192 \\
(\mathrm{Dec})\end{array}$ & $\begin{array}{l}56.92 \\
(56.55)\end{array}$ & $\begin{array}{l}3.51 \\
(3.17)\end{array}$ & $\begin{array}{l}7.81 \\
(7.67)\end{array}$ & - & $\begin{array}{l}15.67 \\
(14.22)\end{array}$ & $\begin{array}{l}4.94 \\
(4.69)\end{array}$ \\
\hline $\mathrm{C}_{12} \mathrm{H}_{7} \mathrm{O}_{3} \mathrm{NS}\left[\mathrm{L}^{2}\right]$ & Yellow & 245 & $\begin{array}{l}138- \\
139\end{array}$ & $\begin{array}{l}58.77 \\
(58.18)\end{array}$ & $\begin{array}{l}2.88 \\
(2.52)\end{array}$ & $\begin{array}{l}5.71 \\
(5.98)\end{array}$ & $\begin{array}{l}13.07 \\
(13.54)\end{array}$ & & \\
\hline $\mathrm{C}_{24} \mathrm{H}_{14} \mathrm{O}_{6} \mathrm{~N}_{2} \mathrm{~S}_{2} \mathrm{CoCl}_{2}$ & Brown & 620.34 & $\begin{array}{l}195- \\
197\end{array}$ & $\begin{array}{l}46.47 \\
(46.09 \\
)\end{array}$ & $\begin{array}{l}2.27 \\
( \\
2.11)\end{array}$ & $\begin{array}{l}4.52 \\
(4.63)\end{array}$ & $\begin{array}{l}10.34 \\
(10.22)\end{array}$ & $\begin{array}{l}9.47 \\
(9.13)\end{array}$ & $\begin{array}{l}11.43 \\
(11.09)\end{array}$ \\
\hline $\mathrm{C}_{24} \mathrm{H}_{18} \mathrm{O}_{8} \mathrm{~N}_{2} \mathrm{~S}_{2} \mathrm{NiCl}_{2}$ & $\begin{array}{l}\text { Dark } \\
\text { green }\end{array}$ & 656.13 & oily & $\begin{array}{l}43.93 \\
(43.12 \\
)\end{array}$ & $\begin{array}{l}2.77 \\
(2.09 \\
)\end{array}$ & $\begin{array}{l}4.27 \\
(4.50)\end{array}$ & $\begin{array}{l}9.77 \\
(9.22)\end{array}$ & $\begin{array}{l}8.95 \\
(8.21)\end{array}$ & $\begin{array}{l}10.81 \\
(10.51 \\
)\end{array}$ \\
\hline $\mathrm{C}_{24} \mathrm{H}_{14} \mathrm{O}_{6} \mathrm{~N}_{2} \mathrm{~S}_{2} \mathrm{CuCl}_{2}$ & Silver & 624.95 & $\begin{array}{l}190- \\
192\end{array}$ & $\begin{array}{l}46.12 \\
(45.91)\end{array}$ & $\begin{array}{l}2.26 \\
(2.19)\end{array}$ & $\begin{array}{l}4.48 \\
(4.66)\end{array}$ & $\begin{array}{l}10.26 \\
(10.01)\end{array}$ & $\begin{array}{l}10.17 \\
(9.98)\end{array}$ & $\begin{array}{l}11.35 \\
(11.12)\end{array}$ \\
\hline $\begin{array}{l}{\left[\mathrm{C}_{24} \mathrm{H}_{14} \mathrm{O}_{6} \mathrm{~N}_{2} \mathrm{~S}_{2} \mathrm{Cd}\right][\mathrm{OAC}]} \\
{\left[\mathrm{C}_{26} \mathrm{H}_{22} \mathrm{O}_{10} \mathrm{~N}_{2} \mathrm{~S}_{2} \mathrm{Cd}\right]}\end{array}$ & Brown & 721.01 & $\begin{array}{l}252- \\
254 \\
\text { dec }\end{array}$ & $\begin{array}{l}46.64 \\
(46.14 \\
)\end{array}$ & $\begin{array}{l}2.80 \\
\text { ( } 2.67 \\
\text { ) }\end{array}$ & $\begin{array}{l}3.89 \\
(3.96)\end{array}$ & $\begin{array}{l}8.89 \\
(8.72)\end{array}$ & $\begin{array}{l}15.59 \\
\text { ( } 15.43\end{array}$ & - \\
\hline$\left[\mathrm{C}_{24} \mathrm{H}_{14} \mathrm{O}_{6} \mathrm{~N}_{2} \mathrm{~S}_{2} \mathrm{Cd}\right] \mathrm{Cl}_{2}$ & Grey & 673.82 & $\begin{array}{l}260- \\
262 \\
\text { dec }\end{array}$ & $\begin{array}{l}46.64 \\
(46.13)\end{array}$ & $\begin{array}{l}2.80 \\
(2.43)\end{array}$ & $\begin{array}{l}3.89 \\
(3.98)\end{array}$ & $\begin{array}{l}8.89 \\
(8.67)\end{array}$ & $\begin{array}{l}15.59 \\
(15.33 \\
)\end{array}$ & $\begin{array}{l}10.52 \\
(10.21)\end{array}$ \\
\hline
\end{tabular}

${ }^{a}$ Dec: Decomposed,calc :Calculated, ${ }^{b}$ Content of metal was done by flame atomic absorption spectroscopy.

Table 2.FT-IR absorptions of the ligands $\mathrm{L}^{1}$ and $\mathrm{L}^{2}$ and theirmetal complexes in $\mathrm{cm}^{-1}$.

\begin{tabular}{|c|c|c|c|c|c|c|c|c|c|}
\hline Compound & vOH & vNH & $v \mathbf{C}=\mathbf{O}$ & $v \mathbf{C}=\mathbf{N}$ & $\mathbf{v C}=\mathrm{C}$ & vS-C, & $\begin{array}{l}\text { vM- } \\
\mathbf{N}\end{array}$ & vM-O & $\begin{array}{l}\text { Other } \\
\text { band }\end{array}$ \\
\hline$\left[\mathrm{L}^{1}\right]$ & 3455 & 3292 & 1649 & $\begin{array}{l}1622 \\
1580\end{array}$ & 1554 & - & & & $\begin{array}{l}\text { 3088- } \\
\text { CHAr }\end{array}$ \\
\hline $\mathrm{Co}\left[\left(\mathrm{L}^{1}\right){ }_{2} \mathrm{Cl}_{2}\right] \cdot \mathrm{H}_{2} \mathrm{O}$ & $3650(\mathrm{br})$ & - & 1649 & $\begin{array}{l}1593- \\
1559\end{array}$ & $\begin{array}{l}1556- \\
1545\end{array}$ & - & $\begin{array}{l}424- \\
472\end{array}$ & 542 & $\begin{array}{l}3023 \\
2933\end{array}$ \\
\hline $\mathrm{Ni}\left[\left(\mathrm{L}^{1}\right)_{2} \mathrm{Cl}_{2}\right] \cdot \mathrm{H}_{2} \mathrm{O}$ & 3440(br) & - & $\begin{array}{l}1664- \\
1651\end{array}$ & 1622 & 1554 & - & 455 & 542 & $\begin{array}{l}3088 \\
2987\end{array}$ \\
\hline $\mathrm{Cu}\left[\left(\mathrm{L}^{1}\right)_{2} \mathrm{Cl}_{2}\right] \mathrm{H}_{2} \mathrm{O} .1 / 2 \mathrm{C}_{2} \mathrm{H}_{5} \mathrm{OH}$. & $\begin{array}{l}3200- \\
3600(\mathrm{br})\end{array}$ & - & 1645 & 1624,1585 & 1566,1533 & - & $\begin{array}{l}434- \\
489\end{array}$ & $\begin{array}{l}511- \\
599\end{array}$ & $\begin{array}{l}3012 \\
2901\end{array}$ \\
\hline$\left[\mathrm{CdL}^{\mathrm{I}}\right]\left(\mathrm{CH}_{3} \mathrm{COO}\right)_{2}$ & & - & 1654 & 1634 & 1568 & - & 445 & 523 & 3022 \\
\hline$\left[\mathrm{CdL}^{1}\right] \mathrm{Cl}_{2}$ & & - & 1656 & 1611,1599 & 1579 & - & 434 & 546 & $\begin{array}{l}3043 \\
2926\end{array}$ \\
\hline
\end{tabular}




\begin{tabular}{|c|l|l|l|l|l|l|l|l|l|}
\hline $\mathrm{L}^{2}$ & 3354 & - & 1714 & 1606 & 1556 & & & & 3117 \\
\hline $\mathrm{Co}\left[\mathrm{L}^{2}\right]_{2}$ & & - & 1716 & 1606 & 1550 & & & 620,754 & 3089 \\
\hline $\mathrm{Ni}\left[\mathrm{L}^{2}\right]_{2} \mathrm{H} 2 \mathrm{O}$ & 3340,3302 & & 1714 & 1630,1606 & 1558 & 1292,1249 & & 624,752 & 3120,932 \\
\hline $\mathrm{Cu}\left[\mathrm{L}^{2}\right]_{2}$ & & & 1728,1718 & 1635,1606 & 1560 & 1244, & & 622,758 & 3148 \\
\hline$\left[\mathrm{C}_{24} \mathrm{H}_{14} \mathrm{O}_{6} \mathrm{~N}_{2} \mathrm{~S}_{2} \mathrm{Cd}\right]\left[\mathrm{CH}_{3} \mathrm{COO}\right]_{2}$ & 3483 & & 1712,1631 & 1606 & 1564 & 1327,1288 & & 612,756 & 3182 \\
\hline $\mathrm{Cd}\left[\mathrm{L}^{2}\right]_{2} \mathrm{Cl}_{2}$ & - & - & 1728,16 & 1606 & 1590 & 1367,1290 & & 634,725 & 3128 \\
\hline
\end{tabular}

* s: strong , m: medium ,br: Broad, w: Weak, sh :shoulder.

Table 3.The electronic spectra and molar conductance of the prepared complexes.

\begin{tabular}{|c|c|c|c|c|c|c|c|c|}
\hline Complex & $\begin{array}{l}\text { UV- } \\
\text { visible, } \\
\lambda \text { nm }\end{array}$ & $\mathbf{v} \mathbf{C m}^{-1}$ & $\begin{array}{l}\text { Tentative } \\
\text { assignment }\end{array}$ & Dq & $\begin{array}{l}\boldsymbol{\beta} \\
\text { Nephelaxeti } \\
\mathrm{c}\end{array}$ & $\begin{array}{l}\boldsymbol{\mu} \\
\text { (B.M. } \\
\text { ) }\end{array}$ & $\begin{array}{l}\Lambda_{\mathrm{m}}(\mathrm{S} . \mathrm{m} \\
\mathrm{ol}^{-} \\
\left.{ }^{1} . \mathrm{cm}^{2}\right)\end{array}$ & Geometry \\
\hline $\mathrm{L}^{1}$ & $\begin{array}{l}310 \\
255\end{array}$ & $\begin{array}{l}32258 \\
39215\end{array}$ & $\begin{array}{l}\mathrm{n} \rightarrow \pi^{*} \\
\pi \rightarrow \pi^{*}\end{array}$ & & & - & & - \\
\hline$\left[\mathrm{Co}\left(\mathrm{L}^{1}\right){ }_{2} \mathrm{Cl}_{2}\right] \cdot \mathrm{H}_{2} \mathrm{O}$ & $\begin{array}{l}656 \\
401 \\
368\end{array}$ & $\begin{array}{l}15243 \\
24937 \\
27173\end{array}$ & $\begin{array}{l}{ }^{4} \mathrm{~T}_{1 \mathrm{~g}} \rightarrow{ }^{4} \mathrm{~T}_{2 \mathrm{~g}} \\
{ }^{4} \mathrm{~T}_{1 \mathrm{~g}} \rightarrow{ }^{4} \mathrm{~A}_{2 \mathrm{~g}(\mathrm{p}} \\
\text { С. } \mathrm{T}\end{array}$ & 969.4 & 1.39 & 3.77 & 22 & Octahedral \\
\hline$\left[\mathrm{Ni}\left(\mathrm{L}^{1}\right)_{2} \mathrm{Cl}_{2}\right] \cdot \mathrm{H}_{2} \mathrm{O}$ & $\begin{array}{l}410 \\
396\end{array}$ & $\begin{array}{l}24096 \\
25252\end{array}$ & $\begin{array}{l}{ }^{3} \mathrm{~A}_{2} \mathrm{~g} \rightarrow{ }^{3} \mathrm{~T}_{2} \mathrm{~g} \\
{ }^{3} \mathrm{~A}_{2} \mathrm{~g} \rightarrow{ }^{3} \mathrm{~T}_{1} \mathrm{~g}\end{array}$ & $\begin{array}{l}2409 . \\
6\end{array}$ & 2.33 & 2.6 & 27 & Octahedral \\
\hline $\begin{array}{c}{\left[\mathrm{Cu}\left(\mathrm{L}^{\mathrm{l}}\right)_{2} \mathrm{Cl}_{2}\right]} \\
\mathrm{H}_{2} \mathrm{O} .1 / 2 \mathrm{C}_{2} \mathrm{H}_{5} \mathrm{OH}\end{array}$ & $\begin{array}{l}871 \\
424 \\
307\end{array}$ & $\begin{array}{l}11481 \\
23584 \\
32578\end{array}$ & $\begin{array}{l}{ }^{2} \mathrm{~B}_{1} \mathrm{~g} \rightarrow{ }^{2} \mathrm{~B}_{2} \mathrm{~g} \\
{ }^{2} \mathrm{~B}_{1} \mathrm{~g} \rightarrow{ }^{2} \mathrm{E}_{2} \mathrm{~g} \\
\mathrm{LMCT}\end{array}$ & - & - & 1.7 & 28 & Octahedral \\
\hline$\left[\mathrm{Cd}\left(\mathrm{L}^{1}\right)_{2}\right] \mathrm{Cl}_{2} \mathrm{H} 2 \mathrm{O}$ & $\begin{array}{l}393 \\
361\end{array}$ & $\begin{array}{l}25445 \\
27700\end{array}$ & $\begin{array}{l}\text { C.T } \\
n \rightarrow \pi^{*}\end{array}$ & - & - & 0.0 & 92 & Tetrahedral \\
\hline$\left[\mathrm{CdL}^{\mathrm{I}}\right]\left(\mathrm{CH}_{3} \mathrm{COO}\right)_{2}$ & $\begin{array}{l}401 \\
365\end{array}$ & $\begin{array}{l}24937 \\
27397\end{array}$ & $\begin{array}{l}\text { C.T } \\
\mathrm{n} \rightarrow \pi^{*}\end{array}$ & & & 0.0 & 101 & Tetrahedral \\
\hline $\mathrm{L}^{2}$ & $\begin{array}{l}366 \\
330\end{array}$ & $\begin{array}{l}27322 \\
30303\end{array}$ & $\begin{array}{l}\text { C.T } \\
n \rightarrow \pi^{*}\end{array}$ & & & 0.0 & & \\
\hline$\left[\mathrm{Co}\left(\mathrm{L}^{2}\right)_{2} \mathrm{Cl}_{2}\right]$ & $\begin{array}{l}848 \\
357 \\
293\end{array}$ & $\begin{array}{l}11792 \\
28011 \\
34129\end{array}$ & $\begin{array}{l}{ }^{4} \mathrm{~T}_{1 \mathrm{~g}} \rightarrow{ }^{4} \mathrm{~T}_{2 \mathrm{~g}} \\
{ }^{4} \mathrm{~T}_{1 \mathrm{~g}} \rightarrow{ }^{4} \mathrm{~A}_{2 \mathrm{~g}(\mathrm{p}} \\
\text { C. } \mathrm{T}\end{array}$ & 1621 & 1.66 & 3.4 & & octahedral \\
\hline$\left[\mathrm{Ni}\left(\mathrm{L}^{2}\right)_{2} \mathrm{Cl} 2\right] \mathrm{H} 2 \mathrm{O}$ & $\begin{array}{l}840 \\
550 \\
293\end{array}$ & $\begin{array}{l}11904 \\
18181 \\
34129\end{array}$ & $\begin{array}{l}{ }^{3} \mathrm{~A}_{2} \mathrm{~g} \rightarrow{ }^{3} \mathrm{~T}_{2} \mathrm{~g} \\
{ }^{3} \mathrm{~A}_{2} \mathrm{~g} \rightarrow{ }^{3} \mathrm{~T}_{1} \mathrm{~g} \\
\text { C. } \mathrm{T}\end{array}$ & 1190 & 1.15 & 2.8 & & octahedral \\
\hline$\left[\mathrm{Cu}\left(\mathrm{L}^{2}\right)_{2} \mathrm{Cl}_{2}\right]$ & $\begin{array}{l}864 \\
357\end{array}$ & $\begin{array}{l}11574 \\
28011\end{array}$ & $\begin{array}{l}{ }^{2} \mathrm{~B}_{1} \mathrm{~g} \rightarrow{ }^{2} \mathrm{~B}_{2} \mathrm{~g} \\
{ }^{2} \mathrm{~B}_{1} \mathrm{~g} \rightarrow{ }^{2} \mathrm{E}_{2} \mathrm{~g}\end{array}$ & & & 1.76 & & octahedral \\
\hline
\end{tabular}




\begin{tabular}{|c|c|c|c|c|c|c|c|c|}
\hline $\mathrm{Cd}\left[\mathrm{L}^{2}\right]_{2} \mathrm{Cl}_{2}$ & $\begin{array}{l}378 \\
340\end{array}$ & $\begin{array}{l}26455 \\
29411\end{array}$ & $\begin{array}{l}\text { C.T } \\
\mathrm{n} \rightarrow \pi^{*}\end{array}$ & - & - & 0.0 & 97 & Tetrahedral \\
\hline $\begin{array}{c}{\left[\mathrm{C}_{24} \mathrm{H}_{14} \mathrm{O}_{6} \mathrm{~N}_{2} \mathrm{~S}_{2} \mathrm{Cd}\right]\left[\mathrm{CH}_{3} \mathrm{CO}\right.} \\
\mathrm{O}]_{2}\end{array}$ & $\begin{array}{l}393 \\
336\end{array}$ & $\begin{array}{l}25445 \\
29761\end{array}$ & $\begin{array}{l}\text { C.T } \\
\mathrm{n} \rightarrow \pi^{*}\end{array}$ & - & - & 0.0 & 109 & Tetrahedral \\
\hline
\end{tabular}

Table(4) .Decomposition steps with the temperature range and weight loss for some complexesof $L^{1}$.

\begin{tabular}{|c|c|c|c|c|c|}
\hline Compound & $\begin{array}{l}\text { Decomposition } \\
\text { step }\end{array}$ & $\begin{array}{l}\text { Temperature } \\
\text { range }\left({ }^{\circ} \mathrm{C}\right)\end{array}$ & $\begin{array}{l}\text { removes } \\
\text { species }\end{array}$ & $\begin{array}{l}\text { Weight } \\
\text { loss \% } \\
\text { (Cald.) }\end{array}$ & $\begin{array}{l}\text { Weight } \\
\text { Loss\%Found }\end{array}$ \\
\hline $\mathrm{Co}\left[\mathrm{L}^{1}\right]_{2}$ & $\begin{array}{l}1 \mathrm{st} \\
2 \mathrm{nd} \\
3 \mathrm{rth}\end{array}$ & $\begin{array}{l}147-181 \\
181-247 \\
247-352\end{array}$ & $\begin{array}{l}\mathrm{H}_{2} \mathrm{O} \\
\mathrm{Cl} \\
\left(\mathrm{C}_{2} \mathrm{H}_{6} \mathrm{~N}_{2} \mathrm{Cl}\right)\end{array}$ & $\begin{array}{l}2.64 \\
5.4 \\
16.72\end{array}$ & $\begin{array}{l}2.04 \\
4.4 \\
16.63\end{array}$ \\
\hline $\mathrm{Cu}\left[\mathrm{L}^{1}\right]_{2}$ & $\begin{array}{l}1 \text { st } \\
2 \text { nd } \\
3 \text { rth } \\
4 \text { rth }\end{array}$ & $\begin{array}{l}45-63.63 \\
63-116.84 \\
116-261 \\
261.8-368\end{array}$ & $\begin{array}{l}1 / 2 \mathrm{C}_{2} \mathrm{H}_{5} \mathrm{OH} \\
\mathrm{Cl}, \mathrm{H}_{2} \mathrm{O} \\
\mathrm{C}_{2} \mathrm{H}_{6} \mathrm{~N}_{2} \mathrm{Cl} \\
\mathrm{C}_{8} \mathrm{H}_{10}\end{array}$ & $\begin{array}{l}3.30 \\
7.2 \\
14.04 \\
19.27\end{array}$ & $\begin{array}{l}3.16 \\
6.95 \\
13.75 \\
18.58\end{array}$ \\
\hline $\mathrm{Cd}\left[\mathrm{L}^{\mathrm{I}}\right]_{2}$ & $\begin{array}{l}1 \mathrm{st} \\
2 \mathrm{nd} \\
3 \mathrm{rd}\end{array}$ & $\begin{array}{l}45-119 \\
119-222 \\
222-351\end{array}$ & $\begin{array}{l}\mathrm{H}_{2} \mathrm{O} \\
2 \mathrm{Cl} \\
\mathrm{C}_{2} \mathrm{H}_{6} \mathrm{~N}_{2}\end{array}$ & $\begin{array}{l}2.44 \\
10.7 \\
18.57\end{array}$ & $\begin{array}{l}2.37 \\
11.9 \\
17.1\end{array}$ \\
\hline
\end{tabular}

\section{Conclusions}

According to the results obtained from elemental analyses, spectral, magnetic susceptibility measurements and the TG-DSC analyses, the octahedral geometry around cobalt, nickel,copper and cadmium (II) ions were suggested and the IR dataadopted the chelation of the two ligands of coumarine derivative via nitrogen of quinoxalinemoiet and carbonyl of chromone ring, Scheme 7. 

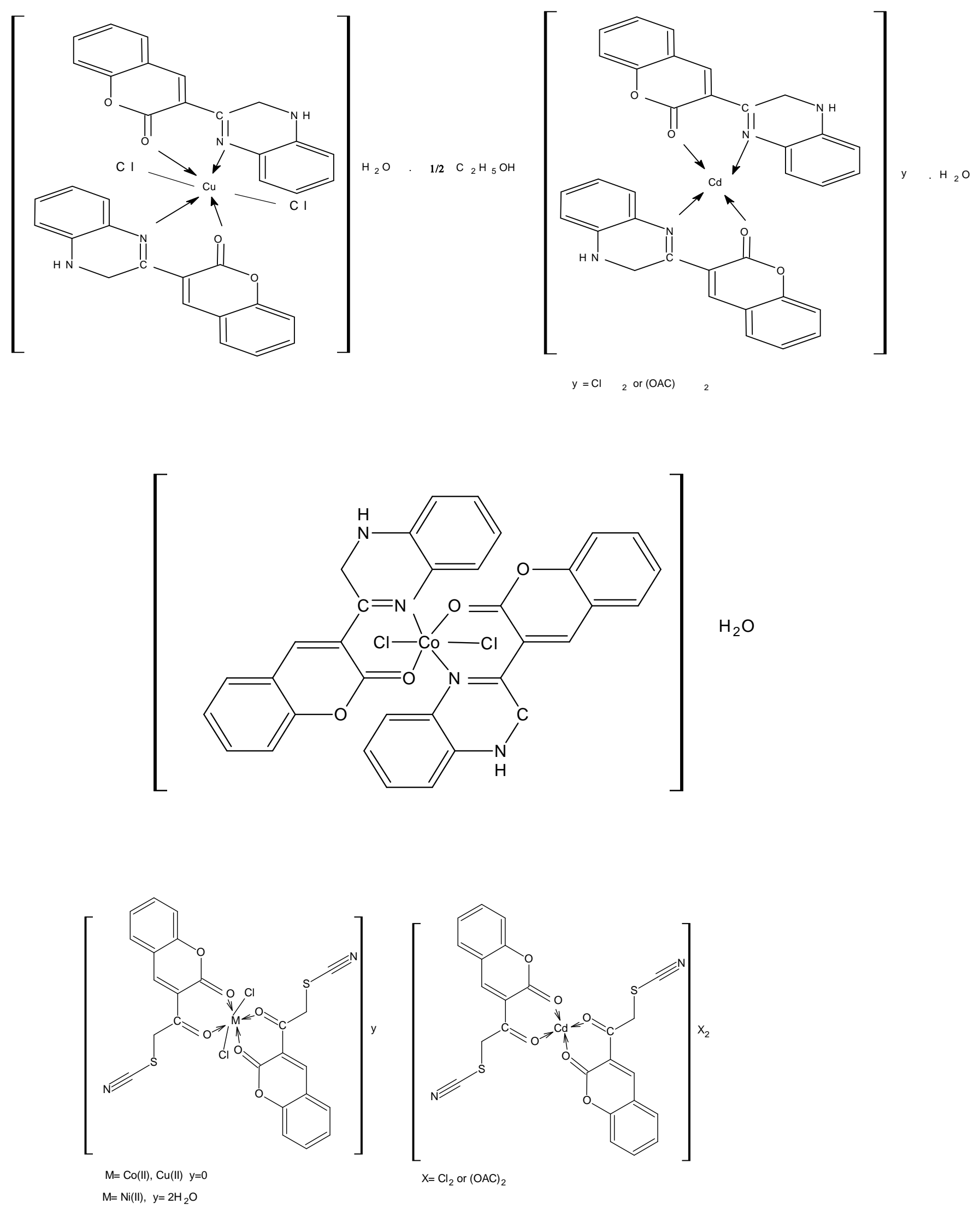
Scheme 7.0ctahedral configurations of the prepared complexes.

\section{Conclusion}

The complexes have the formula :- $\mathrm{M}\left[(\mathrm{L} 1) 2 \mathrm{Cl}_{2}\right] \cdot \mathrm{H}_{2} \mathrm{O}$ where $\mathrm{M}=\mathrm{Co}(\mathrm{II}), \mathrm{Ni}(\mathrm{II}), \mathrm{Cu}\left[(\mathrm{L} 1) 2 \mathrm{Cl}_{2}\right] \mathrm{H}_{2} \mathrm{O}$.

$1 / 2 \mathrm{C}_{2} \mathrm{H}_{5} \mathrm{OH}$.The thermal analyses of complexes shows significant weight losses corresponding to the elimination of ethanol and water molecules per mononuclear unit in the $650 \mathrm{C}$ and $100-120{ }^{\circ} \mathrm{C}$ ranges respectively. Therefore,

onewater molecule are outside coordination sphere, whereas the $\mathrm{Cd}(\mathrm{II})$ are outside the coordination sphere for both it's chloride and acetate complexes.

\section{References}

1.A. Carta, G. P., M. Nikookar, P. Sanna, L. Sechi, S. Zanetti, Eur. J. M ed. Chem. 37

(2002) 355-366.

2.A.J. Bel_enZarranz, Ignacio Aldana, Antonio M onge, Bioorg. M ed. Chem. 12

(2004) 10.

3.A.P. Carlos Barea, Denis Castillo, M irkoZimic, M iguel Quiloano, Silvia Galiano,

Silvia P_erez-Silanes, Antonio M onge, Eric Deharo, Ignacio Aldana, Bioorg. M ed.

Chem. Lett. 21 (2011) 4.

4.Naveen Kulkarni, V.K. R, B.N. Kirasur, M allinath H. Hugar, M ed. Chem. Res. 21

(2012) 8.

5.A. Patidar, J. M., A. M obiya, G. Selvam, Int. J. PharmTech Res. 3 (2011)

386-392.

6.K. Watanabe, H. Oguri, H. Oikawa, Curr. Opin. Chem. Biol. 13 (2) (2009)

189-196;

7.B. Dietrich, U. Diederichsen, Eur. J. Org. Chem. 2005 (1) (2005) 147-153.

8.J. Brown Desmond, C. T. E., A. Ellman Jonathan, The Chemistry of Heterocyclic Compounds, Wiley, 2004. 
9.D. Aparicio, O.A. Attanasi, P. Filippone, R. Ignacio, S. Lillini, F. Mantellini, F. Palacios, J.M. Santos d. I, J. Org. Chem. 71 (16) (2006) 5897-5905.

10.V. Kunkuma, L.A.P.D. Bethala, Y. Bhongiri, B.N.P. Rachapudi, S.S.P. Potharaju, Eur. J. Chem. 2 (4) (December 2011);

11. Ayman A, Abdel-Shafi M, Khalil M H,Hossam HA. Ramadan M R. Ruthenium, osmiumand rhodium-2,3-bis(2\$-pyridyl) quinoxaline complexes. Trans. M et. Chem. 2002;27:69-74.

12. Kulkarni N.V., Gurunath SK, Srinivasa B, Vidyanand K, Revankar K. Spectroscopy, structure, and electrochemistry of transition metal complexes having [M 2N2OS2] coordination sphere. J. Coord. Chem. 2010;63(18):3301-3312.

14.Geary WJ. The use of molar conductivitymeasurements in organic solvents forcharacterization of Inorganic and Coordination Compounds.Coord. Chem. Rev. 1971;7:81122.

15. Silverstein RM , Bassler GC, M orril TC. Spectrometric Identification of Organic Compounds, 4th Ed.; John Wiley \& Sons; 1981.

16. Nakamoto K. 3rd edition. Infrared andRaman spectra of Inorganic andCoordinationCompounds.Wiley, NewYork; 1997.

17. M ohamed A, Gehad GM , M ohamed M O, Mamdouh M N, Ahmed BK. Synthesis, spectroscopic and thermal characterization of quinoxaline metal Complexes. Eur. J.

Chem. 2010;4(1):282-288.

18.M. Vieira, C. Pinheiro, R. Fernandes, J.P. Noronha, C. Prudencio, Microbiol. Res. 169 (4) (2014) 287-293.

19. M ahmoud NA. Synthesis, characterization and biological study of template complexes derived from 2,6-diaminopyridine and quinoxaline-2,3-dione. Eur. Chem. Bull. 2014;3(4):384-389. 
20. Cotton FA, Wilkinson G, M urillo CA,Bochmann M. Advanced Inorganic Chemistry, 6th Edn, Wiley, New York; (1999). 